\title{
Disturbed fibrinolysis in patients with inflammatory bowel disease. A study in blood plasma, colon mucosa, and faeces
}

\author{
E DE JONG, $R$ J PORTE, E A R KNOT, J H VERHEIJEN, AND J DEES
}

From the Department of Internal Medicine II, University Hospital Rotterdam-Dijkzigt and TNO Gaubius Institute, Leiden, The Netherlands

SUMMARY Using specific assays, we studied fibrinolytic activity in plasma and colonic mucosa biopsies of 28 patients with inflammatory bowel disease (IBD) (12 with Crohn's disease, 16 with ulcerative colitis) and 28 control patients without inflammatory bowel disease or colon malignancy. Blood coagulation was studied using standard techniques. In plasma of IBD patients significantly decreased tissue type plasminogen activator activity $(t-P A)(p<0 \cdot 02)$, increased plasminogen activator inhibition (PAI) $(p<0.01)$ and fibrinogen $(p<0.001)$, and prolonged thrombin time $(p<0.001)$ and prothrombintime $(p<0.001)$ were found. In colon mucosa the percentage of t-PA to urokinase type plasminogen activator (u-PA) was $80: 20 \%$ in the control group and $71: 29 \%$ in the IBD group in non-inflamed mucosa. In inflamed mucosa the plasminogen activator percentage was $55: 45 \%$, significantly different $(p<0 \cdot 01)$ from the control group. There was also a significant absolute increase in u-PA activity and decrease of $t-P A$ activity in the inflamed mucosa compared to the control group $(\mathrm{p}<0.001$ and $\mathrm{p}<0.01$, respectively). Patients with inflammatory bowel disease therefore have significant changes in components of the fibrinolytic and coagulation system both systemically and locally in colon mucosa. These changes might contribute to an increased risk for thromboembolic complications and possibly to the pathogenesis of the colitis and to the local complications such as bleeding.

Kwaan et $a l^{12}$ showed for the first time an increased fibrinolytic activity in rectal mucosa in patients with an active colitis. Kondo et $\mathrm{l}^{3}$ found the same results, and suggested that this increased local fibrinolytic activity could influence anal blood loss in these patients. They treated ulcerative colitis patients with the antifibrinolytic agent tranexamic acid, administered as an enema. The patients in whom an increased local fibrinolytic activity was found improved clinically on this therapy with a significant reduction in blood loss, which was also reported in patients with ulcerative colitis treated with tranexamic acid orally. ${ }^{4}$ These two studies, however,

Address for correspondence: E de Jong, Smith Kline \& French b.v., P.O. box 1928, 2280 DX Rÿswÿk Z-H, The Netherlands.

Accepted for publication 28 July 1988. were uncontrolled and limited to 17 patients in whom only local fibrinolysis was investigated with the few tests on fibrinolysis available at that time. Kwaan et al $^{12}$ used a histochemical fibrin slide method, which is a non-specific and non-quantitative method for measuring activity of components of the fibrinolytic system. Kondo et al,$^{3}$ used plasminogen rich and plasminogen poor fibrin plates, showing that the increased fibrinolytic activity was indeed caused by plasminogen activator(s). This method, however, does not discriminate between the two types of plasminogen activators that are distinguished to date: urokinase type plasminogen activator (u-PA) and tissue type plasminogen activator (t-PA). Both plasminogen activators are glycoproteins, capable of converting plasminogen into plasmin, and both glycoproteins are present in blood plasma as well as 
in many body tissues. Disturbances in one or both proteins have been detected in various disorders such as thrombotic disease, ${ }^{5}$ unexplained bleeding, ${ }^{6}$ and cancer. ${ }^{78}$ From the literature we know that thromboembolism is an accepted complication of inflammatory bowel disease, but the involvement of coagulation proteins is still a matter of debate..$^{2.13}$ Recent research has indicated that disturbed fibrinolysis can also account for thromboembolic events. ${ }^{14}$ Until now, however, no specific data on fibrinolysisproteins in the systemic circulation of patients with inflammatory bowel disease are available. Therefore, in order to clarify specifically the nature and magnitude of the disturbances in fibrinolysis and their relation with anal blood loss and disease activity in patients with inflammatory bowel disease, we investigated fibrinolysis, systemically as well as locally, in two groups of gastroenterology patients, with and without inflammatory bowel disease, using recently developed specific chromogenic substrate assays. ${ }^{15} 16$

\section{Methods}

\section{PATIENTS}

Plasma samples, colon mucosal biopsies and 24 hour faeces samples were collected from 56 patients who visited the outpatient department for gastroenterology. The patients were subdivided into a colitis and a control group. The colitis group included 28 patients with histologically proven inflammatory bowel disease. Twelve patients had Crohn's disease, 16 patients had ulcerative colitis. Disease activity indexes were calculated according to van $\mathrm{Hees}^{17}$ or Truelove $^{18}$ (Table 1). Nine patients suffered from pancolitis, and six patients were in remission at the time of the investigation. The control group, comprised 28 patients having non-inflammatory bowel disease (Table 1), who visited the outpatient department of gastroenterology at the same day and hour as their matching case of the colitis group. The exclusion criteria for both groups were malignant tumours, objectively diagnosed thromboembolic disorders, anticoagulant therapy, blood transfusion within the - last two weeks or other concomitant diseases at the time of the investigation. In the colitis group, biopsies were taken from normal colon mucosa $(n=19)$ as well from inflamed mucosa $(n=22)$. In the control group, colon mucosal biopsies were taken only from macroscopically normal mucosa. The study was approved by the Medical Ethic committee of the University Hospital and informed consent was obtained from all patients.

COAGULATION AND FIBRINOLYSIS IN PLASMA Venous blood was collected, between 9 am and 5 pm
Table 1 Characteristics of the patient groups

\begin{tabular}{lll}
\hline & Colitis patients & Control patients \\
\hline N & 28 & 28 \\
Age (mean in years) & $41 \cdot 2$ & $46 \cdot 1$ \\
Men & 14 & 14 \\
Women & 14 & 14 \\
Crohn's disease & 12 & - \\
Ulcerative colitis & 16 & - \\
Activity index:* & & \\
$\quad$ Mild & 15 & - \\
$\quad$ Moderate & 8 & - \\
Severe & 5 & - \\
Irritable bowel syndrome & - & 4 \\
$\quad$ Polyps & - & 8 \\
$\quad$ Diverticulosis & - & 2 \\
$\quad$ No abnormalities & - & 14 \\
\hline
\end{tabular}

*According to van Hees ${ }^{17}$ and Truelove ${ }^{18}$.

after a rest period of at least 10 minutes. The first few millilitres of blood were discarded. Nine millilitres of blood was collected with minimal stasis in a polycarbonate tube containing $1 \mathrm{ml}$ ice cold disodium citrate dihydrate $(0.11 \mathrm{~mol} / \mathrm{l})$ or potassium-EDTA $(1.5 \mathrm{mg} / \mathrm{ml}$ blood $)$. Plasma was separated immediately by centrifugation for 30 minutes at $2000 \mathrm{~g}$ at $4^{\circ} \mathrm{C}$, snap frozen and stored at $-70^{\circ} \mathrm{C}$ in small aliquots. Activated partial thromboplastin time (APTT) was determined with Actin ${ }^{\mathrm{r} 19}$ (Merz Dade, Dijdingen, Switzerland) (N: 25-35s). Thrombin time (ThT) was measured by adding $200 \mu \mathrm{l}$ thrombin $( \pm 3$ $\mathrm{IU} / \mathrm{ml}$ ) to $200 \mu \mathrm{l}$ prewarmed plasma ${ }^{20}$ (thrombin obtained from Merz Dade, Dijdingen, Switzerland) (N: 9-13s). Prothrombin time (PT) was assayed according to Quick, ${ }^{21}$ with Simplastin ${ }^{\mathrm{r}}$ (General Diagnostics, Morris Plane, New Jersey, USA) (N: 15-19s). Factor II was measured using human brain thromboplastin and Factor II deficient plasma (Diamed, Salm and Kipp, Amsterdam, The Netherlands) and expressed in IU/ml (N: 0.80-1·20). Antithrombin III (AT-III) activity was measured using an amidolytic method ${ }^{22}$ with the synthetic peptide substrate S-2238 (Coatest ${ }^{r}$ antithrombin KabiVitrum BV, Amsterdam, The Netherlands) and expressed in IU/ml ( $\mathrm{N}$ : $0 \cdot 85-1.20 \mathrm{U} / \mathrm{ml})$. Alpha-2-plasmin inhibitor (Alpha-2-AP) activity was assayed according to Friberger et $\mathrm{al}^{23}$ using Coatest ${ }^{\mathrm{r}}$ antiplasmin (KabiVitrum BV, Amsterdam, The Netherlands) and expressed in $\mathrm{IU} / \mathrm{ml}(\mathrm{N}: 0.85-1.20 \mathrm{U} / \mathrm{ml})$. Plasminogen was measured according to Friberger ${ }^{23}$ using streptokinase (KabiVitrum BV, Amsterdam, The Netherlands). Fibrinogen was measured according to Clauss. ${ }^{24}$ Tissue type plasminogen activator ( $t$ PA) activity was measured by the spectrophotometric assays according to Verheijen et al. ${ }^{16}$ Before measuring t-PA, euglobulin fractions were prepared 
from rapidly thawed plasma by diluting 1 volume of plasma in 9 volumes ice cold distilled water and 0.75 volumes of $0.25 \%(\mathrm{v} / \mathrm{v})$ acetic acid. The mixture was incubated in melting ice for $\mathbf{3 0}$ minutes, and subsequently centrifuged at $3000 \mathrm{~g}$ at $4^{\circ} \mathrm{C}$ for 10 minutes. After removal of the supernatant the precipitate was dissolved in 1 volume $0.10 \mathrm{~mol} / \mathrm{l}$ Tris. $\mathrm{HCl}, 0.1 \%$ (v/v) Tween-80, $\mathrm{pH} 7 \cdot 7$. T-PA activity was measured by mixing $25 \mu$ l euglobulin fraction to a final volume of $250 \mu \mathrm{l}$ with $0 \cdot 10 \mathrm{~mol} / \mathrm{T}$ Tris. $\mathrm{HCl} \mathrm{pH} \mathrm{7 \cdot 5,0 \cdot 1 \%} \mathrm{(v/v)}$ Tween-80, $0.30 \mathrm{mmol} / 1 \quad \mathrm{H}-\mathrm{D}-\mathrm{Val}-\mathrm{Leu}-\mathrm{Lys}-\mathrm{pNA}$ (S-2251, KabiVitrum, Stockholm, Sweden). Each euglobulin sample was assayed in the presence and in the absence of rabbit IgG against human t-PA. The absorbances at $405 \mathrm{~nm}$ were recorded at regular intervals during two to six hours on a Titertek Multiscan spectrophotometer (Flow Laboratories). The difference between the absorbance with and without antibodies was used to calculate the t-PA activity. The intra-assay reproducibility is $5.5 \%$ (standard deviation) and the inter-assay reproducibility measured on different days $12.5 \%$ (standard deviation) both for a single measurement of a sample with $25-50 \mathrm{mIU} / \mathrm{ml}$ t-PA in the assay. T-PA activity was expressed in International Units (IU) per $\mathrm{ml}$ of plasma.$^{25}$ Inhibition of t-PA in plasma was measured according to Verheijen et al. ${ }^{26}$ Briefly, varying amount of purified t-PA were added to a fixed amount of plasma $(10-25 \mu \mathrm{l})$. The remaining t-PA activity was measured by the spectrophotometric assay. The inhibition level was determined by extrapolation and expressed in IU t-PA ${ }^{25}$ inhibited per $\mathrm{ml}$ of plasma.

FIBRINOLYSIS IN COLON MUCOSAL BIOPSIES Colon mucosal biopsies were obtained during routine endoscopic procedures. The samples were wrapped in parafilm and put into small Eppendorf cups, snap frozen and stored at $-70^{\circ} \mathrm{C}$. To prepare the homogenates, all biopsies were washed in $0.9 \% \mathrm{NaCl}$ to remove visible traces of blood. After determining the individual weights of each biopsy, homogenates were made using a Elvehjem homogeniser and $500 \mu \mathrm{l} \mathrm{Tris/}$ Tween buffer (0.1 M Tris $\mathrm{HCl}, 0.1 \%$ Tween-80, $\mathrm{pH}$ 7.5). After centrifugation for 10 minutes at $10 \cdot 000 \mathrm{~g}$ at $4^{\circ} \mathrm{C}$, the supernatant was stored at $-70^{\circ} \mathrm{C}$ in small aliquots. Using the supernatant of the centrifuged homogenates, urokinase-type (u-PA) and tissue type plasminogen activator ( $t-\mathrm{PA})$ activity were measured by a modification of the method according to Verheijen et al. ${ }^{16}$ Briefly, $10 \mu$ l of each supernatant was measured without antibodies, in the presence of rabbit anti-t-PA IgG or goat anti-urokinase monospecific antibodies and in the presence of both antibodies. The differences in absorbances at $405 \mathrm{~nm}$ of samples with and without antibodies were used to calculate the t-PA, the u-PA activity and the residual amidolytic activity (RAA). In this method the conversion of plasminogen to plasmin by plasminogen activator activity (PA) is inhibited by anti-t-PA, anti$\mathrm{u}-\mathrm{PA}$ or both antibodies respectively. The absorption increase caused by t-PA and u-PA was proportional to the concentration of t-PA and $u-P A$ according to the square of time (plasminogen is converted by PA to active plasmin, resulting in an increase of plasmin concentration, proportionally with time. The formed plasmin simultaneously degrades the chromogenic substrate S-2251, measured at $405 \mathrm{~nm}$, resulting in an increase of absorption with squared time). When both antibodies were added, only a linear increase of absorption in time was observed (complete quenching of PA), resulting from residual amidolytic activity. Cross reactivity was excluded by summation of the quenching rates of both antibodies and residual amidolytic activity, which resulted in absorption equal to the unquenched sample. T-PA was expressed in international units (IU) ${ }^{25}$ per $\mathrm{mg}$ biopsy weight. The amount of $\mathrm{u}-\mathrm{PA}$ in the various samples was calculated from calibration curves obtained with standard u-PA preparations obtained from the National Institute for Biological Standards and Control, London, UK and expressed per mg biopsy weight. The amount of residual amidolytic activity

Table 2 Coagulation and fibrinolytic parameters in plasma

\begin{tabular}{|c|c|c|c|}
\hline Test & (normal values) & $\begin{array}{l}\text { Control patients } \\
n=28 \\
\text { median (range) }\end{array}$ & $\begin{array}{l}\text { Colitis patients } \\
n=28 \\
\text { median (range) }\end{array}$ \\
\hline APTT & $\begin{array}{l}(25-35) \\
(\mathrm{sec})\end{array}$ & $\begin{array}{l}29 \\
(20-33)\end{array}$ & $\begin{array}{l}30 \\
(23-38)\end{array}$ \\
\hline ThT 10 & $\begin{array}{l}(9-13) \\
(\mathrm{sec})\end{array}$ & $\begin{array}{l}11 \\
(9-13)\end{array}$ & $\begin{array}{l}13 \ddagger \\
(10-15)\end{array}$ \\
\hline PT & $\begin{array}{l}(15-19) \\
(\mathrm{sec})\end{array}$ & $\begin{array}{l}17 \\
(13-20)\end{array}$ & $\begin{array}{l}18 \ddagger \\
(16-23)\end{array}$ \\
\hline Faktor II & $\begin{array}{l}(0 \cdot 8-1 \cdot 2) \\
(\mathrm{IU} / \mathrm{ml})\end{array}$ & $\begin{array}{l}0.89 \\
(0.72-1 \cdot 00)\end{array}$ & $\begin{array}{l}0.92 \\
(0 \cdot 70-1 \cdot 00)\end{array}$ \\
\hline AT-III & $\begin{array}{l}(0 \cdot 85-1 \cdot 2) \\
(\mathrm{IU} / \mathrm{ml})\end{array}$ & $\begin{array}{l}1.17 \\
(0.93-1.48)\end{array}$ & $\begin{array}{l}1 \cdot 13 \\
(0 \cdot 69-2 \cdot 10)\end{array}$ \\
\hline Fibrinogen & $\begin{array}{l}(1 \cdot 6-4 \cdot 0) \\
(g / 1)\end{array}$ & $\begin{array}{l}2 \cdot 10 \\
(1 \cdot 20-3 \cdot 20)\end{array}$ & $\begin{array}{l}2.95 \ddagger \\
(1 \cdot 50-4 \cdot 60)\end{array}$ \\
\hline Alpha-2-AP & $\begin{array}{l}(0 \cdot 85-1 \cdot 2) \\
(\mathrm{IU} / \mathrm{ml})\end{array}$ & $\begin{array}{l}1.09 \\
(0.56-1 \cdot 38)\end{array}$ & $\begin{array}{l}1 \cdot 18 \\
(0 \cdot 77-1 \cdot 54)\end{array}$ \\
\hline Plasminogen & $\begin{array}{l}(0 \cdot 85-1 \cdot 2) \\
(\mathrm{IU} / \mathrm{ml})\end{array}$ & $\begin{array}{l}1 \cdot 01 \\
(0.69-1 \cdot 53)\end{array}$ & $\begin{array}{l}1.09 \\
(0.68-1 \cdot 54)\end{array}$ \\
\hline T-PA & $\begin{array}{l}(0-200) \\
(\mathrm{mIU} / \mathrm{ml})\end{array}$ & $\begin{array}{l}123 \\
(0-1138)\end{array}$ & $\begin{array}{l}1 * \\
(0-905)\end{array}$ \\
\hline PAI & $\begin{array}{l}(0-15) \\
(I U / m l)\end{array}$ & $\begin{array}{l}3 \cdot 8 \\
(0-12 \cdot 5)\end{array}$ & $\begin{array}{l}5 \cdot 5 \dagger \\
(0 \cdot 6-25 \cdot 0)\end{array}$ \\
\hline
\end{tabular}

Activated partial thromboplastin time (APTT), Thrombin time (ThT 10), Prothrombin time (PT), Antithrombin-III (AT-III), Alpha-2-plasmin inhibitor (Alpha-2-AP), Tissue-type plasminogen activator (t-PA) and Plasminogen activator inhibition (PAI), see also Figs 1 and $2 .{ }^{*}=p<0.02 ; \dagger=p<0.01 ; \ddagger=p<0.001$, Wilcoxon's. 


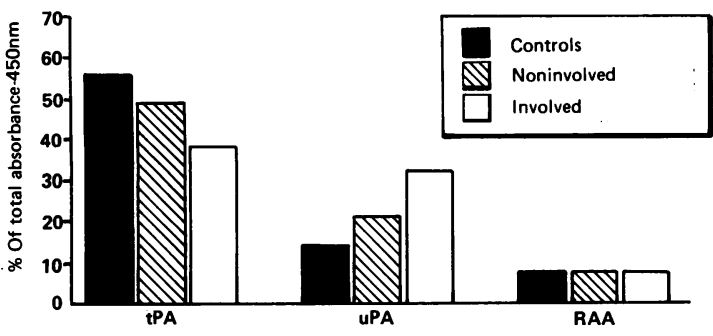

Fig. 3 Percentages of fibrinolytic activity in colon mucosal biopsies. T-PA, u-PA and residual amidolytic activity $(R A A)$ after one hour incubation at $25^{\circ} \mathrm{C}$, are presented as a percentage of the total absorbance $-405 \mathrm{~nm}$.

\section{FIBRINOLYTIC ACTIVITY IN COLON MUCOSAL BIOPSIES}

Fibrinolytic activities in colon mucosal biopsies are given in Table 3 and Figure 3 . In the control patients the percentage of u-PA activity in the mucosa was $20 \%$ of the plasminogen activator content. In the colitis group the percentage of $\mathrm{u}-\mathrm{PA}$ activity in the non-involved mucosa was $29 \%$ of the plasminogen activator content, comparable with the control group. The percentage of u-PA in the involved mucosa of colitis patients $(45 \%$ of the plasminogen activator content) was different, however, compared with the control patients $(\mathrm{p}<0 \cdot 01)$. Differences were found for t-PA in non-involved colitis and involved colitis mucosa versus control mucosa $(p<0.02$ and $\mathrm{p}<0.001$ respectively), but for $\mathrm{u}-\mathrm{PA}$ only for involved colitis mucosa versus control mucosa $(\mathrm{p}<0.01)$. No differences between the residual amidolytic activities (PA quenched by two antibodies) of the three biopsy groups were observed. The total amidolytic activity (unquenched sample expressed in $\Delta$-A405 nm per hour of incubation at $20^{\circ} \mathrm{C}$ ) was also not different in the three biopsy groups. No correlations were observed for t-PA and u-PA in involved or non-involved mucosa versus disease activity indexes.

\section{BLOOD LOSS IN FAECES}

The results of the determination of blood loss in 24hours faeces samples are given in Figure 4. No significant difference was observed between the colitis and the control group. No significant correlations were observed for t-PA and u-PA in colon mucosa or disease activity indexes versus faecal blood loss.

\section{Discussion}

The results of our study can be divided into the results from plasma, the biopsies supernatants and faeces. In plasma we found a small but significant rise

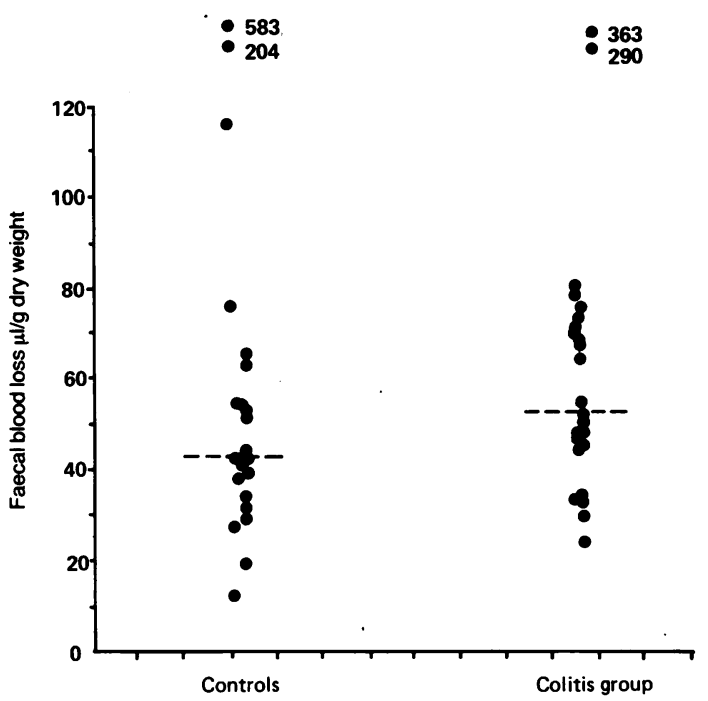

Fig. 4 Faecal blood loss in the two patient groups, expressed in $\mu \mathrm{l} / \mathrm{g}$ dry weight. Colitis group median 53 , range 23-363; control group median 43, range 12-585 (ns).

of plasminogen activator inhibition (PAI) and fibrinogen in the colitis group, which is compatible with the acute phase reaction described for these proteins. ${ }^{29} 30$ The decrease of plasma t-PA might be the result of complex formation with the increased inhibitor(s) (PAI). It is now known that patients with high PAI concentrations are at risk for developing deep venous thrombosis ${ }^{14}$ and our observation of increased PAI concentrations in colitis patients could help explain the known risk of thromboembolic disorders in colitis patients. ${ }^{121}$ The significant difference between thrombin time and prothrombin time in the colitis group could be caused by increased fibrinogen concentrations and decreased vitamin $\mathrm{K}$ absorption, which is known to occur in these patients. ${ }^{32}$

The results of the fibrinolysis parameters in colon mucosa showed a shift towards the urokinase-type plasminogen activator in the inflamed mucosa of the colitis patients. This was also published in an abstract by Elliot $e t a^{33}$ presenting qualitative data. Our quantitative t-PA concentrations were significantly decreased in non-involved, and even more in involved mucosa, an observation that correlates well with the finding of Kwaan et $\mathrm{al}^{3}$ who found prolonged lysis times, indicating decreased plasminogen activation concentrations, in relation to submucosal blood vessels in mucosal biopsies obtained from patients with active colitis. Whether locally increased plasminogen activator inhibitor, as a possible consequence of the observed increase of PAI in plasma of 
the patients with colitis, could be responsible for the decreased levels of t-PA measured in the biopsies remains to be investigated. Quantitatively, urokinasetype plasminogen activator concentrations were significantly increased in involved colitis mucosa compared with non-involved and control mucosa, which is comparable with results recently published in an abstract. ${ }^{34}$ Others have also found an increase of u-PA levels of tumour mucosa in malignant disorders of the colon. ${ }^{35}{ }^{36}$ They concluded that this might be a marker of malignancy. It is, however, also possible that the described increase could be caused by an inflammatory process surrounding the tumour cells. In our study, no difference in residual amidolytic activity could be observed. A decrease in this activity was observed in human colorectal carcinomas by De Bruin et al..$^{35}$ As neither the nature of the substances responsible for this activity nor the importance of the differences in PA-activity between inflammation and malignancy are clear at present, this difference merits further study. The results of blood loss in faeces showed no difference between the two patient groups. This indicates that the disturbances in fibrinolysis in colon mucosa we found in this study do not imply a significant increase in faecal blood loss in these patients. In conclusion we can say that complex disturbances in fibrinolysis are present in patients with inflammatory bowel disease, locally as well as systemically. In plasma these disturbances may contribute to the known risk for thromboembolic complications, but in colon mucosa it is not clear whether these disturbances might contribute to increased or sustained mucosal bleeding.

Part of this study was presented at the First International Fibrinolysis Workshop on Assays of Plasminogen Activators and their Inhibitors. April 18, 1986, Leiden, The Netherlands.

\section{References}

1 Kwaan HC, Cocco A, Mendeloff AI. Histologic demonstration of plasminogen activation in rectal biopsies from patients with active ulcerative colitis. $J$ Lab Clin Med 1964; 64: 877.

2 Kwaan HC, Cocco A, Mendeloff AI, Astrup T. Fibrinolytic activity in the normal and inflamed rectal mucosa. Scand J Gastroenterol 1969; 4: 441-5.

3 Kondo M, Hotta $T$, Takemura $T$, Yoshikawa $T$, Fukumoto K. Treatment of ulcerative colitis by direct administration of an antifibrinolytic agent as an enema. Hepatogastroenterology 1981; 28: 270-3.

4 Hollanders D, Thomson JM, Schofield PF. Tranexamic acid therapy in ulcerative colitis. Postgrad Med J 1982; 58: 87-91.

5 Wiman B. The role of the fibrinolytic system in thrombotic disease. Acta Med Scand 1987; 715 [Suppl]: 16971.
6 Booth NA, Bennett B, Wijngaards G, Grieve JHK. A new lifelong hemorrhagic disorder due to excess plasminogen activator. Blood 1983; 61: 267-75.

7 Dano K, Andreasen PA, Grondahl-Hansen J, Kristensen P, Nielsen LS, Skriver L. Plasminogen activators, tissue degradation and cancer. Adv Cancer Res 1985; 44: 139-266.

8 De Jong E, Knot EAR, Piket D, et al. Increased plasminogen activator inhibition levels in malignancy. Thromb Haemostas 1987; 57: 140-3.

9 Lake AM, Stauffer JQ, Stuart MJ. Hemostatic alterations in inflammatory bowel disease. Dig Dis 1978; 23: 897-902.

10 Lam A, Borda LT, Inwood MJ, Thompson S. Coagulation studies in ulcerative colitis and Crohn's disease. Gastroenterology 1975; 68: 245-51.

11 Mori Kazuo, Watanga Hikaru, Hiwatshi Nubuo, et al. Studies on bloodcoagulation in Ulcerative colitis and Crohn's disease. Tohoku J Exp Med 1980; 132: 93-101.

12 Lee JCL, Spittell J, Sauer WG, Owen CA, Thompson JH. Hypercoagulability associated with chronic ulcerative colitis: changes in blood coagulation factors. Gastroenterology 1968; 54: 76-84.

13 Knot EAR, Ten Cate JW, Leeksma OCh, Tytgat GN, Vreeken $\mathbf{J}$. No evidence for a prethrombotic state in stable chronic inflammatory bowel disease. J Clin Pathol 1983; 36: 1387-90.

14 Juhan-Vague I, Valadier J, Alessi MC, et al. Deficient $t$-PA release and elevated PA inhibitor levels in patients with spontaneous or recurrent deep venous thrombosis. Thromb Haemostas 1987; 1: 67.

15 Kluft C. Blood fibrinolysis, proactivators and activators in human plasma. University of Leiden: Thesis. Pijnacker, The Netherlands: Dutch Efficiency Bureau, 1978.

16 Verheijen JH, Mullaart E, Chang, CTG, Kluft C, Wijngaards G. A simple, sensitive spectrophotometric assay for extrinsic (tissue-type) plasminogen activator applicable to measurement in plasma. Thromb Haemostas 1982; 48: 266-9.

17 Hees PAV, Eteren Van PH, Lier Van HJJ, Tongeren J. An index of inflammatory activity in patients with Crohn's disease. Gut 1980; 21: 279-86.

18 Truelove SC, Witts LJ. Cortisone in ulcerative colitis. Br Med J 1955; ii: 1041-54.

19 Bascu D, Gallus A, Hirsh J, Cade J. A prospective study. of the value of monitoring heparin treatment with the activated partial thromboplastin time. $N$ Engl $J$ Med 1972; 287: 324-7.

20 Penner JA. Experience with a thrombotic clotting time assay for measuring heparin activity. Am J Clin Pathol 1974; 61: 645-53.

21 Quick AJ, Stanley-Brown M, Bancroft FW. A study of the coagulation defect in hemophilia and jaundice. Am J Med Sci 1935; 190: 501-11.

22 Kahle LH, Schipper HG, Jenkins CSP, et al. Antithrombin-III: evaluation of an automated AT-III method. Thromb Res 1978; 12: 1003-14.

23 Friberger P, Knos M, Gustavsson S, Aurell L, Claeson G. Methods for the determination of plasmin, antiplasmin and plasminogen by means of substrate S-2251. Haemostasis 1978; 7: 138-45. 
24 Clauss A. Gerinnerungsphysiologische schnellmethode zur bestimmung des fibrinogens. Acta Haematolol (Basel) 1957; 17: 237-46.

25 Gaffney PJ, Curtis AD. A collaborative study of a proposed international standard for tissue-type plasminogen activator. Thromb Haemostas 1985; 53: $134-6$.

26 Verheijen JH, Chang GTG, Kluft C. Evidence for the occurrence of fast-acting inhibitor for tissue-type plasminogen activator in human plasma. Thromb Haemostas 1984; 51: 392-5.

27 Ahlquist DA, McGill DB, Schwarz S, Tayler WF, Owen RA. Fecal blood levels in health and disease, a study using Hemoquant. $N$ Engl J Med 1985; 312: 1422-8.

28 Van den Berg JWO, Edixhoven-Bosdijk A, KooleLesuis R, Wilson JHP. Faecal haem assay some practical modifications of the haemoquant assay for haemoglobin in faeces. Clin Chem Acta 1987; 169: 319-22.

29 Emeis JJ. Factors affecting plasminogen activator inhibitor (PAI) activity levels in experimental animals [Abstract]. Fibrinolysis 1986; 1: 69.

30 Koj A. In: Ciba Foundation Symposium. Energy metabolism in trauma. London: Churchill Livingstone, 1970 79.
31 Knot EAR, Ten Cate JW, Bruin T, Iburg AHC, Tytgat GNJ. Antithrombin-III metabolism in two colitis patients with acquired antithrombin-III deficiency. Gastroenterology 1985; 89: 421-5.

32 Harvey A, Johns RJ, Owens AH, Ross RS, eds. In: The principles and practice of medicine. Appleton Century Crofts, 1976: 841-63.

33 Elliott R, Stephens RW, Doe WF. Implication of urokinase-type plasminogen activator in the pathogenesis of inflammatory bowel disease (IBD) [Abstract]. Gastroenterology 1984; 5: 1069.

34 Sim PS, Stephens R, Fayle DRH, Doe WF. Urokinasetype plasminogen activator expression in inflammatory bowel disease tissue - quantitation of pro- and active enzyme levels [Abstract]. Gastroenterology 1986; 5: 1634.

35 De Bruin PAF, Verspaget HW, Griffioen G, Nap M, Verheijen JH, Lamers CBHW. Plasminogen activator activity and composition in human colorectal carinomas. Fibrinolysis 1987; 1: 57-62.

36 Gelister JSK, Mahmoud M, Lewin MR, Gaffney PJ, Boulos PB. Plasminogen activators in human colorectal neoplasia. Br Med J 1986; 293: 728-31. 